\title{
RELATIONSHIP OF BRAIN NATRIURETIC PEPTIDE WITH SERUM LIPIDS AND BODY MASS INDEX IN HEALTHY ADULT MALES
}

\section{DR. MEH JABEEN}

Assistant Professor Physiology

Hamdard College of Medicine and

Dentistry Hamdard University Karachi

\section{DR. MOHAMMAD FURQAN}

Professor and Head

Department of Physiology

Hamdard College of Medicine and Dentistry

Hamdard University Karachi

\section{DR. MOHSIN TURAB}

Assistant Professor Pharmacology Hamdard College of Medicine and Dentistry

Hamdard University Karachi

\section{Dr. Shah Murad \\ Professor and Head of Pharmacology Department, Lahore Medical \& Dental College, Lahore}

\section{Dr. Zulfiqar-ul-Hassan}

Associate Professor Pharmacology

Lahore Medical \& Dental College

Lahore

Dr. Ghazi Mahmood

Senior Registrar ENT

Ghurki Trust Teaching Hospital

Lahore

Article Citation:

Jabeen M, Furqan M, Turab M, Murad S, Zulfiqar-ul-Hassan, Mahmood G. Relationship of brain natriuretic peptide with serum lipids and body mass index in healthy adult males. Professional Med J Jun 2010;17(2): 274-278.

\begin{abstract}
Prevalence of morbid obesity has increased dramatically world wide during past three decades. BNP a cardiac lipolytic hormone is found to be decreased in obese hypertensive and heart failure patients. Increasing values of BMI are associated with dyslipidemia. Objective: To find out the relationship of BNP with increasing values of BMI and individual serum lipid fractions in apparently healthy adult males. Study Design: Observational, cross-sectional study. Setting: Department of Physiology at Basic Medical Sciences Institute, Jinnah Post Graduate Medical Center, Karachi. Material \& Methods: Study included 85 adult males, aged between 20-60 years. All were nonsmokers, non- diabetic, having no other chronic illness and not taking any lipid lowering therapy. Study participants were evaluated for lipid profile and divided into three groups for the calculated BMI values according to WHO and International Obesity Task Force. Brain Natriuretic Peptide was assayed by AxSym technology. Results: Brain Natriuretic Peptide developed a negative correlation with BMI, total and LDLcholesterol and a positive relation with HDL-cholesterol and triglycerides. Conclusions: This study concluded that Brain Natriuretic Peptide is negatively related with increasing values of BMI and degree of dyslipidemia in apparently healthy adult males.
\end{abstract}

Key words: Brain Natriuretic Peptide, Serum Lipids, Body Mass Index.

\section{INTRODUCTION}

The morbid obesity has been postulated as the leading modifiable cause of cardiovascular disease in Asia $^{1}$ and its prevalence has doubled in the past decade ${ }^{2}$. Ventricular BNP release being transcriptionally regulated by cardiac wall stretch $^{3}$ is inversely related to BMI in obese patients ${ }^{4}$. Suppressed plasma BNP levels are also reported in obese individuals with heart failure ${ }^{5,6}$. Raised triglycerides and low HDL-cholesterol are related to obesity $^{7}$. BNP does not correlate with serum lipids ${ }^{11}$.
BNP through its lipolytic and lipomobilizing effects ${ }^{8}$ reduce the incidence of overweight and obesity ${ }^{9}$. No

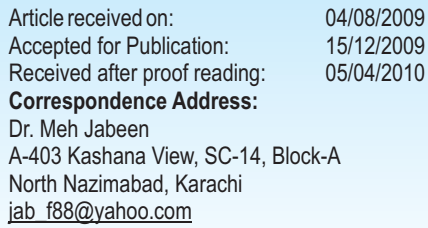


study was found to disclose the relation of BNP with individual serum lipid fractions and the increasing values of BMI in apparently healthy adult males. So this study was designed to achieve these goals.

\section{MATERIALAND METHODS}

This study was carried out during February to October 2007 at Basic Medical Sciences Institute JPMC, Karachi.

\section{INCLUSION CRITERIA}

This study included a total of 85 apparently healthy males ranging between the ages of 20-60 years. The selected subjects had no history of any chronic systemic illness. All were non-smokers and not taking any lipid lowering therapy.

\section{EXCLUSION CRITERIA}

Exclusion was made on the basis of history and lab findings (TLC $>10.9 \times 10^{9} / \mathrm{L}$ or $<3.9 \times 10^{\circ} / \mathrm{L}$, C-Reactive protein $>6 \mathrm{mg} / \mathrm{L}$, Serum Creatinine $>1.1 \mathrm{mg} / \mathrm{dl}$, Fasting Blood Sugar $>115 \mathrm{mg} / \mathrm{dl}$ ). Blood samples from the subjects were collected between 8 to 10AM after a fast of 12 to 14 hours. Samples were preserved at $-20^{\circ} \mathrm{C}$. BNP was determined by AxSYM technology based on microparticle enzyme immunoassay (MEIA) using kit Reference No.8G82-20ABBL001/R4 provided by Abbot Diagnostic Laboratories. Serum triglycerides, total cholesterol and
HDL-cholesterol were determined by enzymatic colorimetric method. LDL-cholesterol was estimated according to Friedwald formula.

Body Mass Index(BMI) was calculated as:-

Weight $(\mathrm{Kg}) /$ Height $\left(\mathrm{m}^{2}\right)$

Subjects of the population were divided each into two groups on the basis of individual lipid type as desirable and undesirable values respectively according to National cholesterol education programme, Adults treatment Pannel-III (ATP-III) ${ }^{19}$.

To study the relationship between BMI and BNP levels population was divided into three groups on the basis of their calculated BMI values as Lean $(<20)$, Normal $(20$ $25)$ and Overweight $(>25)$ according to $\mathrm{WHO}$ and International Obesity Task Force ${ }^{20}$.

\section{RESULTS}

In our study BNP could not develop any statistically significant relationship with serum lipids. Coefficient of correlation $(r)$ between BNP and lipid profile disclosed a positive relationship with HDL-cholesterol and triglycerides while a negative relationship with total and LDL-cholesterol as shown in Table-I.

\begin{tabular}{|c|c|c|c|c|c|c|}
\hline \multicolumn{2}{|l|}{ Lipid Profile } & $\mathrm{n}$ & Mean $(\mathrm{pg} / \mathrm{ml})$ & \pm SEM & P-value & R-value \\
\hline \multirow[t]{2}{*}{ Cholesterol (mg/dl) } & $<200$ & 76 & 22.8 & 3.83 & \multirow{2}{*}{0.284} & \multirow{2}{*}{-0.03} \\
\hline & $\geq 200$ & 9 & 10.6 & 3.62 & & \\
\hline \multirow[t]{2}{*}{ Triglyceride (mg/dl) } & $<150$ & 66 & 21.1 & 3.66 & \multirow{2}{*}{0.843} & \multirow{2}{*}{0.14} \\
\hline & $\geq 150$ & 19 & 22.8 & 9.05 & & \\
\hline \multirow[t]{2}{*}{$\mathrm{HDL}(\mathrm{mg} / \mathrm{dl})$} & $<35$ & 14 & 20.3 & 11.26 & \multirow{2}{*}{0.877} & \multirow{2}{*}{0.03} \\
\hline & $\geq 35$ & 71 & 21.7 & 3.54 & & \\
\hline \multirow[t]{2}{*}{ LDL (mg/dl) } & $\leq 100$ & 43 & 27.2 & 5.88 & \multirow{2}{*}{0.099} & \multirow{2}{*}{-0.12} \\
\hline & $>100$ & 42 & 15.7 & 3.44 & & \\
\hline
\end{tabular}


BNP levels were found to be low in dyslipidemics when compared with controls as shown in Table-Il.

A decrease in BNP levels from 29.1 to $18.7 \mathrm{pg} / \mathrm{dl}$ was found with the increasing values of BMI and dyslipidemia. Hence a negative but statistically non-significant corelation was found between BNP and BMI $(P<0.642 r=-$ $0.10)$ as shown in Table-III.
Table-II. BNP levels in Dyslipidemics and Controls.

\begin{tabular}{|l|c|c|c|c|}
\cline { 1 - 3 } Lipid Status & $\mathbf{n}$ & Mean (pg/ml) & \pm SEM & P-value \\
\hline Normal & 37 & 23.7 & 5.37 & 0.566 \\
\cline { 1 - 3 } Dyslipidemia & 48 & 19.7 & 4.56 & \\
\hline
\end{tabular}

\begin{tabular}{|c|c|c|c|c|c|c|}
\hline \multicolumn{7}{|c|}{ Table-III. BNP and Lipid Profile according to BMI. } \\
\hline BMI & No. of object & $\begin{array}{c}\text { Triglyceride (mg/dl) } \\
\text { Mean } \pm \text { SEM }\end{array}$ & $\begin{array}{c}\text { Cholesterol (mg/dl) } \\
\text { Mean } \pm \text { SEM }\end{array}$ & $\begin{array}{c}\text { HDL (mg/dl) } \\
\text { Mean } \pm \text { SEM }\end{array}$ & $\begin{array}{c}\text { LDL (mg/dl) } \\
\text { Mean } \pm \text { SEM }\end{array}$ & $\begin{array}{c}\text { BNP (pg/ml)I } \\
\text { Mean } \pm \text { SEM }\end{array}$ \\
\hline \multicolumn{7}{|c|}{} \\
\hline$<20$ & 6 & $95.5 \pm 15.47$ & $157.0 \pm 11.11$ & $41.2 \pm 1.17$ & $97.2 \pm 10.69$ & $29.1 \pm 10.1$ \\
\hline $20-25$ & 33 & $134.8 \pm 10.70$ & $165.6 \pm 5.25$ & $38.3 \pm 0.90$ & $99.5 \pm 4.58$ & $24.0 \pm 6.22$ \\
\hline$>25$ & 46 & $137.3 \pm 11.14$ & $163.8 \pm 4.32$ & $38.7 \pm 0.79$ & $97.5 \pm 3.59$ & $18.7 \pm 3.47$ \\
\hline \multicolumn{7}{|c|}{$P=0.642 ; \quad r=-0.10$} \\
\hline
\end{tabular}

\section{DISCUSSION}

BNP one of the member of natriuretic peptide family is secreted mainly by ventricular myocardium and plays its role via interactions with NPR-A receptors ${ }^{3}$. NPR-A binding sites are present on human fat cell membranes and BNP has been found to a potent lipolytic and lipomobilizing hormone through a cGMP-dependent protein kinase signaling pathway independent of cAMP production and PKA activity. BNP via such effects can change the metabolic state and reduce the incidence of overweight and obesity by influencing lipid metabolism.BNP levels are significantly lower in obese patients with advanced heart failure ${ }^{5,6}$. Wang et a ${ }^{10}$ also demonstrated an inverse relationship between BNP and obesity while others have not found this association ${ }^{11}$. Finding of lower circulating BNP levels in obese patients has cast a doubt about utility of this biomarker in patients with a high BMI, a population of patients in whom evaluation is often challenging owing to the effects of their weight on clinical histories and particularly physical examination findings.

Raised triglycerides and low HDL-cholesterol both are related to obesity ${ }^{7}$. Our study also found that increasing dyslipidemia was responsible for the increase in BMI values as shown in Table-III. An inverse relation between BNP and BMI was found by Iwanaga ${ }^{5}$ and Horwich $^{6}$ in obese heart failure patients while our study found the same but in apparently healthy adult males with progressively rising values of BMl. The link between increasing BMI and low BNP levels is not yet fully elucidated. Probably there may be increased expression of clearance receptors by adipose tissue resulting in clearance of BNP in subjects with increasing $\mathrm{BMI}^{10}$. More recently there is decreased release of BNP from heart rather than increased clearance responsible for such association $^{12,13,14}$. In our study this relationship was independent of age contradicting to $\mathrm{McCord}$ et a ${ }^{15}$ who explained that lower BMI was associated with higher BNP because of a common relation to older age.

The potential contribution of natriuretic peptides in lipid metabolism of human subcutaneous adipose tissue can have physiological repercussions ${ }^{16}$. In this study BNP could not develop any significant relationship with serum lipids as stated by Kanda et $\mathrm{al}^{11}$.While relating BNP with individual lipid fractions in desirable and undesirable states a positive relation with triglycerides and HDL- 
cholesterol and a negative relation with total and LDLcholesterol was disclosed. Our results in context to HDLcholesterol are in accordance with Lupattelli et al ${ }^{17}$ who included only diagnosed severe hyperlipemics in comparison to our gradually changing values. Our results in healthy adults also relate with Michael et $\mathrm{al}^{18}$ who found the same but in patients of metabolic syndrome.

\section{CONCLUSION}

Our study found that BNP is inversely related with the increasing values of BMI, total and LDL-cholesterol and positively related with $\mathrm{HDL}$-cholesterol and triglycerides in healthy adult males. BNP may be valuable as predictor and potential therapeutic target for risk stratification of obesity in primary care by general practitioners and helpful in deciding all those measures which may prevent or delay the establishment of obesity and many cardiovascular complications.

Copyright @ 15 Dec, 2009.

\section{REFERENCES}

1. Cheung BMY. The cardiovascular continuum in Asia-a new paradigm for the metabolic syndrome. J Cardiovasc Pharmacol 2005; 46: 125-129.

2. Freedman DS, Khan LK, Serdula MK et al. Trends and correlates of class 3 obesity in the United states from 1990 through 2000. JAMA.2002; 288: 1758-1761.

3. Woodard GE, Rosado JA. Natriuretic peptides in vascular physiology and pathology. Int Rev Cell Mol Biol.2008; 268: 59-93.

4. Bayes-Genis A, DeFilippi, Januzzi JL Jr. Understanding amino-terminal pro-B-type natriuretic peptide in obesity. Am J Cardiol. 2008 Feb 4; 101(3A): 89-94.

5. Iwanaga Y, Kihara Y, Nizuma S, Noguchi T, Nonogi H, Kita $T$ et al. BNP in overweight and obese patients with heart failure: an analysis based on the BNP-LV diastolic wall stress relationship. J Card Fail.2007 Oct; 13(8):663-7.

6. Horwich TB, Hamilton MA, Fonarow GC. B-type natriuretic peptide levels in obese patients with advanced heart failure. J Am Coll Cardiol. 2006 Jan 3; 47(1): 85-90. Epub 2005 Dec 15.

7. Landsberg L. Insulin resistance and hypertension.
ClinExpHpertens 1999; 21: 885-894. 8. Lafontan M, Moro C, Berlan M, Crampes F, Sengenes C, Galitzky J. Control of lipolysis by natriuretic peptides and cyclic GMP. Trends Endocrinol Metab. 2008 May-Jun; 19(4): 130-7. Epub 2008 Mar 11.

9. Sarzani R, Strazzullo P, Salvi F, lacone R, Pietrucci F, Siani $A$ et al. Natriuretic peptide clearance receptor alleles and susceptibility to abdominal adiposity. Obes Res.2004; 12:351-356.

10. Wang TJ, Larson MG, Levy D, Benjamin EJ, Leip EP, Wilson PW et al. Impact of obesity on plasma natriuretic peptide levels. Circulation. 2004; 109: 594-600.

11. Kanda H, Kita Y, Okamura T, Kadowaki T, Yoshida Y, Nakamura $Y$ et al. What factors are associated with high plasma B-type natriuretic peptide levels in a general Japanese population? J Hum Hypertens.2005; 19: 165172.

12. Das SR, Drazner MH, Dries DLet al. Impact of body mass and body composition on circulating levels of natriuretic peptides: results from the Dallas Heart Study. Circulation 2005; 112: 2163-2168.

13. Van Kimmenade R, van Dielen F, Bakker J et al. Is brain natriuretic peptide production decreased in obese subjects? JAm Cardiol. 2006; 47: 886-887.

14. Minami J, Nishikimi T, Matsuoka H. Plasma brain natriuretic and $\mathrm{N}$-terminal proatrial natriuretic peptide level in obese patients: a cause or result of hypertension? Circulation. 2004; 110: e76.

15. McCord J, Mundy BJ, Hudson MP, Maisel AS, Hollander $\mathrm{JE}$, Abraham WT et al. Relationship between obesity and B-type natriuretic peptide levels. Arch Intern Med. 2004; 164: 2247-2252.

16. Bulow J. Human adipose tissue blood flow during prolonged exercise. Effect of beta-adrenergic blockade, nicotinic acid and glucose infusion. Scand J Clin Lab Investing.1981; 41: 415-424.

17. Lupattelli G, Marchesi S, Siepi D, Bagaglia F, Palumbo B, Roscini AR et al. Natriuretic peptides levels are related to HDL-cholesterol with no influence on endothelium dependent vasodilatation. Vasa. 2006 Nov; 35(4): 21520.

18. Olsen MH, Hansen TW, Christensen MK, Gustafsson F, Rasmussen S, Wachtell $\mathrm{K}$ et al. N-Terminal Pro Brain 
Natriuretic Peptide is inversely related to metabolic cardiovascular risk factors and the metabolic syndrome. Hypertension. 2005; 46:660.

19. National Cholesterol Education Program (NCEP) Expert Panel on Detection, Evaluation, and Treatment of High Blood Cholesterol in Adults (Adult Treatment Panel III). Third Report of the National Cholesterol
Education Program (NCEP) Expert Panel on Detection, Evaluation, and Treatment of High Blood Cholesterol in Adults (Adult Treatment Panel III) final report. Circulation. 2002; 106: 3143-3421.

20. WHO and International Obesity Task Force classification for quantifying obesity with BMl. Davidsons principles and practice of medicine; 20th edition (page: 113).

\section{The line is a dot, that went for a cos alls.}

\section{Shakeel Talat}

